\title{
RENTAL PRICE CONVERGENCE IN A DEVELOPING ECONOMY: NEW EVIDENCE FROM NONLINEAR PANEL UNIT ROOT TEST
}

\author{
Mehmet Huseyin BILGIN ${ }^{\circledR}$, Chi Keung Marco LAU ${ }^{2}$, Ender DEMIR ${ }^{3}$ \\ and Nijolè ASTRAUSKIENE் 4 \\ ${ }^{1}$ Kadir Has University, 34083 Cibali-Fatih, Istanbul, Turkey \\ E-mail: mhbilgin@khas.edu.tr \\ ${ }^{2}$ Zirve University, Klzllhisar Campus, 27260 Gaziantep, Turkey \\ E-mail: kenlau123@hotmail.com \\ ${ }^{3}$ Università Ca’Foscari di Venezia, 30121 Venezia, Italy \\ E-mail: demir.ender@unive.it \\ ${ }^{4}$ Vilnius Gediminas Technical University, Sauletekio al. 11, LT-10223 Vilnius, Lithuania \\ E-mail: nijole.astauskiene@vgtu.lt
}

Received 30 April 2010; accepted 1 July 2010

\begin{abstract}
We examine the hypothesis of nonlinear rental price convergence using relative rental price index of three major cities of Turkey namely, Istanbul, Izmir, and Ankara span from the period from January 1994 to February 2010. Our results indicate that all cities exhibit rental price convergence towards its national mean level for the period of January 1994 to December 2004. In contrast, none of the cities show evidence of convergence from January 2005 to February 2010. The evidence clearly shows rental price divergence in Turkish property market.
\end{abstract}

KEYWORDS: Turkey; Housing industry; Major cities of Turkey; Panel unit root test; Rental price movement

\section{INTRODUCTION}

The world had experienced a house price boom starting from the mid-1990s. During this period, house prices rose by $120 \%$ on average in OECD countries. However, the crises in US sub-prime mortgage market in 2007 which has pushed the world into an economic recession, has ended the expansion. The housing markets outside the US have also been affected dramatically from the crisis (Andre, 2010). The problems in the housing markets have spread and adversely affected other industries which are directly or indirectly related.
The housing industry in Turkey has moved directly related with the general economic conditions of Turkey. The macroeconomic problems in late 1990s, the Russian Crisis in 1998, the earthquake of 17 August 1999¹, economic and political instabilities, and finally

1 Turkey had a serious earthquake on August 17, 1999, which was a 7.6 magnitude earthquake that struck all northwestern of Turkey including Istanbul and many other cities. Izmit, another big city of Turkey, was very badly damaged and the earthquake killing around 17 thousand people and leaving approximately half a million people homeless. 
the financial crisis in 2001 created serious problems in housing industry in Turkey (Turhan, 2008). However, the structural reforms in the banking industry and the political stability have helped to stimulate the economy and so the housing industry to recover in the following years. The growth rate of construction industry in GDP declined dramatically by $17.4 \%$ in 2001 , however after the crisis an average yearly growth rate of $11 \%$ was achieved in the period of 2002-2007 (TurkStat, 2009). The property prices and rents also increased quickly during this period.

Nevertheless, the decreasing demand in housing market result a decline of $3.3 \%$ in the first quarter of 2008 and afterwards the decline has continued. The construction industry shrank by $19.9 \%$ in the first half of 2009 (Republic of Turkey Ministry of Finance, 2009). The housing loans which valued 1.4 billion TL ( 0.85 billion dollar) in 2002 rose to 12.4 billion TL (9.18 billion dollar) in 2005 and 37.5 billion TL (24.67 billion dollar) in $2008^{2}$. The ratio of housing loans to GDP which was less than 1\% before 2004, reached to $4 \%$ in 2008 . New housing loans had shown a decrease starting from the last quarter of 2008 as a result of rising interest rates; however the market has started to recover in the second half of 2009 (ISPAT, 2010).

Turkey is one of the fastest urbanizing countries in the world (Standard and Poors, 2007). Besides, decreasing interest rates, introduction of mortgage market, increasing GDP per capita, the need for renewing the houses and rising population of Turkey has been the major forces of the expansion in housing market in Turkey during 2000s. Nevertheless, housing loans to GDP ratio is still below the level of the Central and Eastern Europe

$\overline{2}$ USD values are calculated by using year-end exchange rates. member states and the average in the Euro Area. Although the unmet demand decreased from $74.1 \%$ in 2002 to $27.8 \%$ in 2008 , the supply in housing industry still yet does not able to meet the demand in Turkey (ISPAT, 2010). There exists a great potential in housing sector in Turkey. Although the housing industry is expanding and getting more important for the economy, a mature literature on the industry does not exist yet in Turkey. Onder et al. (2004), Ozus et al. (2007), and Keskin (2008) focus on the determinants of house prices in Istanbul, whereas Selim (2008) analyzes the house price determinants in Turkey. Moreover, Akin (2008) makes a comprehensive look at the housing market characteristics in Turkey. The lack of house-price/rent index for Turkey has been the major obstacle in the literature development on house and rent prices specifically on the convergence ${ }^{3}$.

This paper tests whether there exist a convergence or divergence of rent price movements in three major cities of Turkey, namely Istanbul, Ankara and Izmir. The rest of the paper is organized as follows. The next section gives a literature review. The section 3 reports the data and methodology. The section 4 shows and discusses the findings of the study. The final section contains the summary and concludes.

\section{LITERATURE REVIEW}

The behavior of house prices and rents has gained interest in the literature especially in the last two decades. The focus has been mostly on the test of the existence of convergence between house prices across countries and

3 Reidin.com has developed INDEX focus on house prices and rents in Turkey covering seven major cities since 2007 and Turkish Statistical Institute is now working on establishment of house price index for Turkey. 
across regions/states in a country ${ }^{4}$. The tests for regional house price convergence are performed mostly for the US and the UK. Klyuev (2008) and Vansteenkiste (2007) find evidence in favor of house price convergence across the US. However, Clark and Coggin (2009) find mixed evidence for regional convergence in the US. The literature on house price movements in the UK is well-developed. The findings for the UK show that house price changes start in the South East and later spread to other regions. This phenomenon is named as "the ripple effect". Over the long-run, the house prices in regions move together. Cook (2003) with asymmetric unit root tests and Cook (2005) with jointly applying DF-GLS test and KPSS stationarity test find supportive evidence for ripple effect in the UK. Likewise, Holmes and Grimes (2005) and Holmes (2007) also indicate the regional house price convergence in the UK. Moreover, MacDonald and Taylor (1993) show many cointegrating relationships for 11 regions in the UK for the period of 19691987 and find weak support for ripple effect. Similarly, Alexander and Barrow (1994) report evidence for the ripple effect and cointegration of house prices. Cook and Thomas (2003) find evidence in favor of ripple effect by using nonparametric testing and business cycle dating techniques. Conversely, Ashworth and Parker (1997) cast doubt on the ripple effect hypothesis. The findings of Drake (1995) indicate the existence of regional differences in the pattern of the UK house price movements. The empirical results mostly support existing regional house price convergence in the UK based on findings of long-run equilibrium relationships (Chien, 2010).

\footnotetext{
4 We skip the literature on cross-country investigation. Please see, Andre (2010), Gros (2007), Otrok and Terrones (2005), Vansteenkiste and Hiebert (2009), Ferrara and Koopman (2009), Tvaronavičienè et al. (2009), and Bilgin et al. (2010) for cross-country investigation.
}

The literature on house price convergence in other countries has also developed in the last decade. Berg (2002) finds that Stockholm area leads price changes in the housing market of six other areas which means the ripple effect for the period from January 1981 to July 1997. Larraz-Iribas and Alfaro-Navarro (2008) focus on regional asymmetries of house prices in Spain and find that Spanish regions groups cointegrate over time. Chien and Lee (2006) find evidence for house price convergence in some regions of Taiwan. Chien (2010) with two-break LM unit test, supports the existence of ripple effects for each city in Taiwan except Taipei City. Burger and Rensburg (2008) find that large and possibly medium middle-segment house prices in these areas converge in South Africa. Luo et al. (2007) indicate the existence of convergence between pairs of housing markets in the eight capital cities of Australia. Likewise, Liu et al. (2008) also find house price diffusion within Australia's state capital cities by indicating the cities Canberra and Hobart as the key engines. Stevenson (2004) finds the house price diffusion from Dublin to the other regions which is similar and consistent with the UK ripple effect.

Contrary to the vast literature on house price movement, the literature lacks studies about rents. Rents are mostly investigated in term of their effects on house prices. Hargreaves (2008) investigates whether the changes in rents affect the changes in New Zealand house prices. The author finds that rents lead prices by 6 months lag. Carrerasi-Solanas et al. (2004) indicate that rents are important in determining house prices. Likewise, Gallin (2008) finds evidence for the longrun relationship between house prices and rents. House prices and rents tend to correct back to each other over 4 year time period in the US. Klyuev (2008) reports a co-integrating relationship between home prices and rents. As the literature exhibits, the test of convergence of rents in three biggest cities of Turkey 
will be helpful in inferring information about the house-price convergence which can not be tested due to lack of data.

In fact, the research about house prices and rent convergence does not exist due to lack of data in Turkey. However, the price convergence on broader terms has been studied. Ozcicek (2007) analyzes the price convergence for 19 Turkish provinces from 1994 to 2003 and finds no evidence of price convergence. Unlikely, Tunay and Silpagar (2007) report the existence of a serious inflation convergence among different geographical regions for the period of 1994-2004. More recently, Akkoyunlu and Siliverstovs (2010) find the existence of a long-run relationship between inflation in two biggest cities of Turkey namely Istanbul and Ankara over the time period of 1922-1998. Yilmazkuday (2009) studies the CPI convergence for different sectors by taking into account the monetary policy. He tests the convergence for housing and rent CPI inflation rates for monthly data for 7 regions of Turkey over the 1994-2004 by using Augmented DickeyFuller test. The results indicate that at least $14 \%$ of the region pairs have converged to each other in terms of housing and rent CPI inflation rents. However, the portion of this convergence is very low compared to convergence portions in Clothing and Footwear, Food, Beverage and Tobacco CPI Inflation Rates. The author put forward two explanations for the reasoning of the difference between convergence portions. The non-tradability of the sector makes it harder for prices and inflation rate to converge to each other. And secondly, the process of migration which is regarded as arbitrage decreasing activity especially for housing industry, will take a longer time period to work. Moreover, he indicates that more regions have converged to each other in terms of housing and rent CPI inflation rates in the inflation-targeting period (after January 2002) compared to the pre-inflation-targeting period. In this study, we focus specifically on the convergence of rent CPI inflation rates by doing the analysis on city level instead of regional level. As suggested by Yilmazkuday (2009), we aim to shed more light on rent price movement across three major cities of Turkey namely Istanbul, Ankara, and Izmir.

\section{EMPIRICAL ANALYSIS}

\subsection{Data and methodology}

The data is collected from the website of the Turkish Statistical Institute (TurkStat). We use the monthly data on rent price index CPI span from January 1994 to February 2010. In this study, we include 3 major cities in Turkey; they are Istanbul, Ankara, and Izmir. These cities are the leading cities of Turkey in many aspects. According to the 2009 population census results of Address Based Population Registration System, Istanbul, Ankara, and Izmir with the population of 12.9 million, 4.6 million and 3.8 million respectively took the first three places in Turkey. Moreover, these three cities are in the first five in terms of export values in 2009. The proportions of these cities in GDP sum up to $36.4 \%$ of Turkey according to 2001 data.

The methodology of unit root test is widely adopted in the economics literature as an econometrics tool to validate the conceptual hypothesis of convergence ${ }^{5}$, and it indicates the convergence hypothesis holds once the

5 For example, Taylor and Taylor (2004) and Lau (2009) among others use the unit root test to test against purchasing power parity. Pedroni and Yao (2006) and Lau (2010) adopt the methodology of linear and nonlinear unit root test to examine the issue of income convergence in China. Bektas (2007) investigates the hypothesis of corporate profit persistence in the Turkish banking system. 
time series in interest is found to be stationary. In the following sections we will discuss the methodology of unit root test in more details. One needs to take note that TurkStat changed its definition of CPI for the regions from which price data are collected for time period after year 2004. However, this will not affect our analysis because the variable that we are interested in is the relative price series, as long as the definition of CPI and its calculation method are the same across regions the analysis and hence the empirical results will not be affected by the change of CPI definition.

\subsection{Univariate augmented Dickey-Fuller (ADF) test}

We first employ monthly rent price index of three major Turkish cities, Istanbul, Izmir, and Ankara, to construct relative price series towards the average of Turkish rent index, such that the series of interest for city $i$ is, at time $t$, is $P_{i, t}$, we have:

$$
y_{i, t}=\ln \left(g_{i, t} / \bar{g}_{t}\right) t=1, \ldots, T
$$

where: $y_{i, t}$ is the relative price series; $g_{i, t}$ is the price index; $\bar{g}_{t}$ is the Turkish rent index.

We can see from Figure 1 and 2 that the relative price differential series becomes widening through time. This result implies price divergence and the observation is obvious for Ankara after year 2001. In order to have a more rigorous assessment about the evidence on Turkish rent price convergence or divergence, we employ univariate unit root test, linear panel unit root test, and non-linear panel unit root test in the following sections.

Consider a series at time $t$,

$$
\Delta y_{1, t}=\alpha_{1}+\beta_{1} y_{1, t-1}+\sum_{j=1}^{K_{1}} \delta_{1, j} \Delta y_{1, t-j}+\mu_{1, t}
$$

where: $\Delta y_{t}$ is the series of interested items in first difference; $\Delta y_{t-1}$ is the augmenting term; $u_{t}$ is the IID error term, i.e. $u_{t} \sim i d\left(0, \sigma^{2}\right)$.

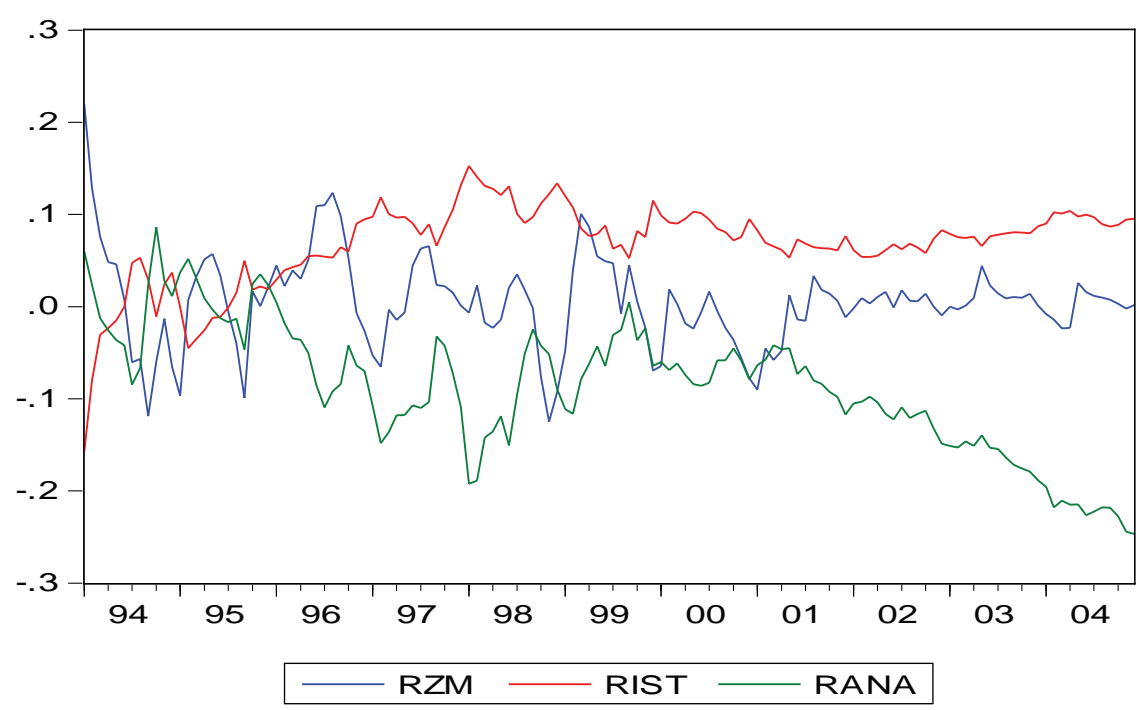

Figure 1. Relative price difference (January 1994 - December 2004) 


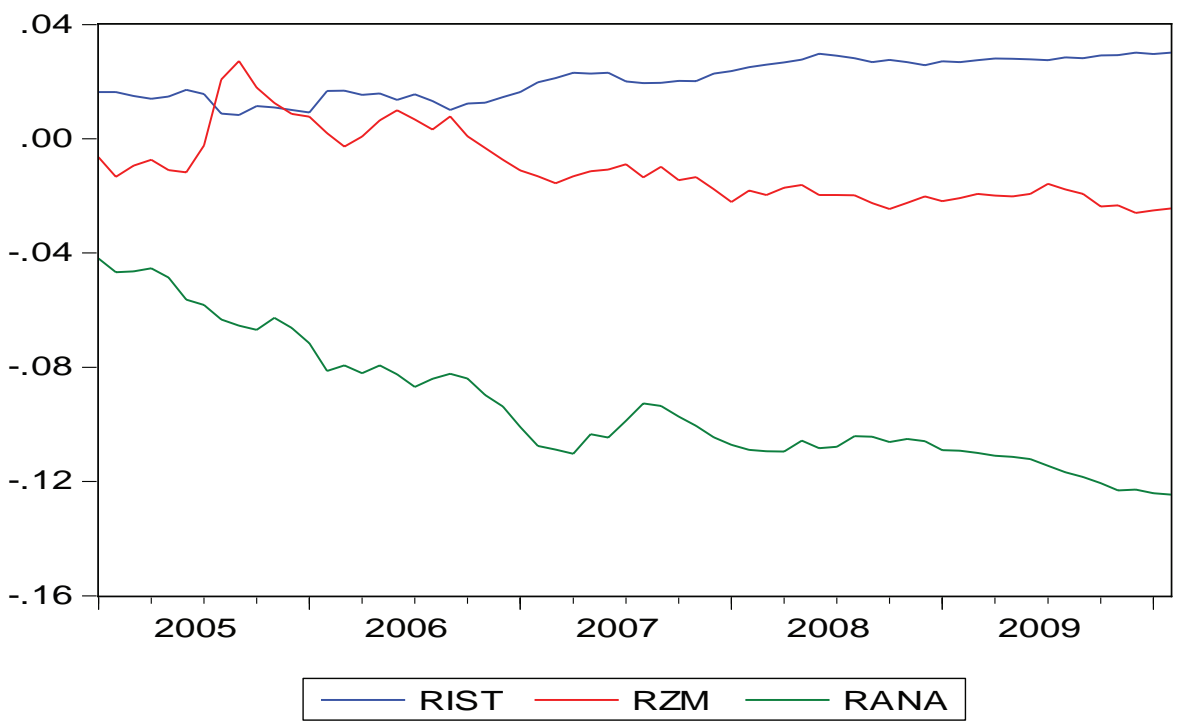

Figure 2. Relative price difference (January 2005 - February 2010)

Equation (2) is estimated by ordinary least square (OLS) and the unit root null hypothesis is rejected when the ADF statistic is found to be significant for the null $b=0$ against the alterative $b<0$. The number of augmenting terms is determined using the Akaiki information criteria (AIC). Table 1 indicates that the null hypothesis of having a unit root is rejected for Izmir, and hence we can conclude that the hypothesis of price convergence is accepted for Izmir only during year 1994 to 2004. In contrast Table 2 shows that the unit-root null hypothesis of price convergence is rejected for all three major cities during year 2005 to 2010.

Table 1. Univariate augmented Dickey-Fuller test (House rental index: 1994-2004)

\begin{tabular}{llll}
\hline City & $B_{i}$ & Test Stat. (p-value\#) & Lag \\
\hline Istanbul & -0.1078 & $-2.6392^{*}$ & 0 \\
Ankara & -0.056 & -2.0183 & 0 \\
Izmir & -0.1439 & $-3.420^{* * *}$ & 1 \\
\hline
\end{tabular}

\# MacKinnon approximate p-value is used.

Note: ${ }^{*}$ and $* * *$ denotes $10 \%$ and $1 \%$ significance level respectively.
Table 2. Univariate augmented Dickey-Fuller test (House rental index: 2005-2010)

\begin{tabular}{llll}
\hline City & $\beta_{\mathrm{i}}$ & Test Stat. (p-value\#) & Lag \\
\hline Istanbul & -0.0118 & -0.3755 & 7 \\
Ankara & -0.0327 & -1.7191 & 1 \\
Izmir & -0.0658 & -1.8562 & 10
\end{tabular}

\# MacKinnon approximate p-value is used.

Note: ${ }^{*}$ and $* * *$ denotes $10 \%$ and $1 \%$ significance level respectively.

Next, we proceed to examine the traditional panel unit root tests and their potential weaknesses when applying to empirical studies.

\subsection{Im et al. (2003) linear panel unit root test}

However, it is well documented in the literature that the $\mathrm{ADF}$ test has low power against the stationary alternative. Maddala and Kim (1998) among others criticize univariate unit root tests for having low power against the stationary alternative. This problem even becomes severe when the sample sizes used are relatively small. Two solutions have been 
considered so far in the literature. The first approach is to adopt the modified version of UADF tests advocated by Elliott et al. (1996), Park and Fuller (1995) and Perron and Ng (1996), based on a weighted symmetric estimator, and the max test suggested by Leybourne (1995); Kwiatkowski et al. (1992) also suggests that taking stationarity as the null can improve power.

The second approach is to explore more information by combining time (T) and space (N) dimension. These panel unit root tests are advocated by Im et al. (2003) and Maddala and Wu (1999) among others. This chapter follows the second approach and presents a panel data estimation procedure that is of more practical importance to researchers. The primary motivation behind the application of panel data unit root tests, as opposed to standard univariate unit root tests is to explore more information by combining time and space dimension to get procedures that are more powerful. The general model for $N$ series and $T$ time periods that of interest is the relative price differential series for city $i$, which has the form:

$y_{1, t}=\alpha_{1}+\theta_{1} y_{1, t-1}+\sum_{j=1}^{K_{1}} \delta_{1, j} \Delta y_{1, t-j}+\mu_{1, t} t=1, \ldots, T$

$$
\vdots \quad \vdots \quad \vdots \quad \vdots \quad \vdots
$$

$y_{i, t}=\alpha_{i}+\theta_{i} y_{i, t-1}+\sum_{j=1}^{K_{i}} \delta_{i, j} \Delta y_{i, t-j}+\mu_{i, t} t=1, \ldots, T$

where: $k_{i}$ is the number of augmenting terms; $\left\{u_{i}\right\}(i=1,2,3)$ are white noise series independently distributed across countries, i.e. $u_{i} \sim i d\left(0, \sigma_{i}^{2}\right)$.

Rearrange equation (3) become:

$\Delta y_{1, t}=\alpha_{1}+\beta_{1} y_{1, t-1}+\sum_{j=1}^{K_{1}} \delta_{1, j} \Delta y_{1, t-j}+\mu_{1, t} t=1, \ldots, T$

$$
\begin{aligned}
& \vdots \quad \vdots \quad \vdots \quad \vdots \quad \vdots \\
& \Delta y_{i, t}=\alpha_{i}+\beta_{i} y_{i, t-1}+\sum_{j=1}^{K_{i}} \delta_{i, j} \Delta y_{i, t-j}+\mu_{i, t} t=1, \ldots, T
\end{aligned}
$$

where: $\Delta$ is the first difference operator; $\beta=(\theta-1)$.

Applying the Augmented Dicky- Fuller test, the null hypothesis and the alternative become:

$$
H_{0, A D F, i}: \beta_{i}=0, H_{1, A D F, i}: \beta_{i}<0(i=1,2, \ldots, N)
$$

Based on the mean of the individual ADF t-statistics of each member in the panel, Im et al. (2003) assume that all series have a unit root under the null hypothesis while there are at least one series is stationary as its alternative. That is:

$$
\begin{aligned}
& H_{0, I P S}: b_{i}=b=0(i=1,2, \ldots, N) \\
& H_{1, I P S}: b_{i}=b<0 \text { for } i=1,2, \ldots, N_{1} \\
& \text { and } \beta_{i}=0 \text { for } i=N_{1}+1, \ldots, N
\end{aligned}
$$

Table 3 shows evidence of convergence on average for three major cities for the period of 1994-2004, while there is lack of evidence of convergence for the period of 2005-2010. Therefore we may conclude that the rental divergence is more serve for the era of globalization in Turkey's property market.

Table 3. IPS panel unit root test

\begin{tabular}{lll}
\hline Test & $\begin{array}{l}\text { Test-Stat. } \\
(1994-2004)\end{array}$ & $\begin{array}{l}\text { Test-Stat. } \\
(2005-2010)\end{array}$ \\
\hline Im et al. (2003) & $-2.5478 * * *$ & 0.2253 \\
p-value & 0.0054 & 0.5891 \\
\hline
\end{tabular}

Note : ${ }^{* * *}$ denotes $1 \%$, significance level.

\subsection{Nonlinear panel unit root test with cross section dependence}

We believe that the rental price evolution dynamics across three major cities in Turkey follows non-linear patterns. The equalization of prices of goods and factors of production follows a non-linear dynamics as shown by many researchers (e.g. Michael et al., 1997; Taylor et al., 2001). These models suggest that 
exchange rate adjustment follows a non-linear path due to the existence of "bands of inaction" in the exchange rate adjustment process. Within the bands, arbitrage of tradable good is not profitable because transaction cost (i.e. the sum of transportation cost, cost of trade barriers, and distribution cost) is greater than the price difference. The existence of "bands of inaction" may come from market frictions raised from trade protectionism or transaction costs (i.e. any costs not directly related to the production of goods and services).

In our study of Turkish property market, we propose that the convergence mechanism, if there are any, should follow nonlinear dynamic process. The rationale behind it is that the sum of transaction cost involved in property market includes among others, agent commission, legal fees, and property tax, and other investment opportunities forgone. Property price and rental price difference will be continuously observed if the profit margin earned from arbitrage activity across cities is not substantial enough to cover the amount of transaction cost.

Therefore, we use the Exponential Smooth Transition Autoregressive (ESTAR) model to specify the price evolvement dynamics across cities. Cerrato et al. (2009) developed a new non-linear panel ADF test under cross-sectional dependence, which is based on the following ESTAR specification, and the model is applied to the de-meaned data series of interest in our study: in its general form, we have:

$$
\begin{aligned}
& \bar{y}_{i t}=\xi_{i} \bar{y}_{i, t-1}+\xi_{i}^{*} \bar{y}_{i, t-1} Z\left(\theta_{i} ; \bar{y}_{i, t-d}\right)+\mu_{i t} \\
& t=1, \ldots, T \quad i=1, \ldots, N
\end{aligned}
$$

where:

$$
Z\left(\theta_{i} ; \bar{y}_{i, t-d}\right)=1-\exp \left[-\theta_{i}\left(\bar{y}_{i, t-d}-c\right)^{2}\right]
$$

where: $\theta_{i}$ is a positive coefficient; $c$ is the equilibrium value of price difference between region $i$ and the mean difference across cities due to heterogeneous factors between region $i$ and the mean value in Turkey rental market.

The initial value, $y_{i 0}$, is given, and the error term, $\mu_{\mathrm{it}}$, has the one-factor structure:

$$
\begin{aligned}
& \mu_{i t}=\gamma_{i} f_{t}+\varepsilon_{i t}, \\
& \left(\varepsilon_{i t}\right)_{t} \sim \text { i.i.d. }\left(0, \sigma_{i}^{2}\right)
\end{aligned}
$$

in which $f_{t}$ is the unobserved common factor, and $\varepsilon_{i t}$ is the individual-specific (idiosyncratic) error. Following the existing literature, the delay parameter $d$ is set to be equal to one so that equation (6) may be rewritten in first difference form in general as:

$$
\begin{aligned}
& \Delta \bar{y}_{i, t}=\alpha_{i}+\xi_{i} \bar{y}_{i, t-1}+\sum_{h=1}^{h-1} \delta_{i j h} \Delta \bar{y}_{i j, t-h}+ \\
& \left(\bar{\alpha}_{i}^{*}+\xi_{i}^{*} \bar{y}_{i, t-1}+\sum_{h=1}^{h-1} \delta_{i h}^{*} \Delta \bar{y}_{i, t-h}\right) * Z\left(\theta_{i} ; \bar{y}_{i, t-d}\right)+ \\
& \gamma_{i} f_{t}+\varepsilon_{i t}
\end{aligned}
$$

notice that when $\bar{y}_{i, t-d}=c, Z(\cdot)=0$ and equation (9) is equivalent to a standard linear ADF model of equation (2). However, when the magnitude of income divergence between $\bar{y}_{i, t-d}$ and $c$ becomes too large, $Z(\cdot) \approx 1$ will generate a new linear ADF model with parameter $\beta_{i}=\xi_{i}+\xi_{i}^{*}$. In contrast, when income divergence is negligible, $\xi_{i}^{*}$ affects the flow of the income differential in this case. However, when the income divergence becomes more serious, $\xi_{i}^{*}$ plays a more important role in governing the adjustment process. We should take note that $\xi_{i}+\xi_{i}^{*}<0$ is the necessary condition for "global stability" to hold. Once the condition of $\xi_{i}+\xi_{i}^{*}<0$ is fulfilled, it is legitimate to have $\xi_{i} \geq 0$; if this occurs, the implication is that the income divergence follows a nonstationary growth path (e.g. a random walk or an explosive innovation within the "band of inaction" of c) and eventually it converges back to its equilibrium once the magnitude of income divergence is outside the "band". If we assume that $\bar{y}_{i, t}$ follows a unit root process in 
the middle regime, then $\xi_{i}=0$ and equation (9) can be rewritten as:

$$
\Delta \bar{y}_{i, t}=\xi_{i}^{*} \bar{y}_{i, t-1}\left[1-\exp \left(-\theta_{i} \bar{y}_{i, t-1}^{2}\right)\right]+\gamma_{i} f_{t}+\varepsilon_{i, t}
$$

The null hypothesis of non-stationarity is $H_{0}: \theta_{\mathrm{i}}=0 \forall i$, against the alternative of : $H_{1}: \theta_{i}>0$ for $i=1,2, \ldots, N_{1}$ and $\theta_{i}=0$ for $i=N_{1}+1, \ldots, N$.

Because $\xi_{i}^{*}$ in equation (10) is not identified under the null, it is not feasible to test the null hypothesis directly. Thus, Cerrato et al. (2009) reparameterize equation (10) by using a firstorder Taylor series approximation and obtain the auxiliary regression

$$
\Delta \bar{y}_{i, t}=a_{i}+\delta \bar{y}_{i, t-1}^{3}+\gamma_{i} f_{t}+\varepsilon_{i, t}
$$

For a more general case where the errors are serially correlated, equation (11) is extended to:

$$
\Delta \bar{y}_{i, t}=a_{i}+\delta \bar{y}_{i, t-1}^{3}+\sum_{h=1}^{h-1} \vartheta_{i h} \Delta y_{i, t-h}+\gamma_{i} f_{t}+\varepsilon_{i, t}
$$

Cerrato et al. (2009) further prove that the common factor $f_{t}$ can be approximated by

$$
f_{t} \approx \frac{1}{\tilde{\gamma}} \Delta \tilde{y}_{t}-\frac{\bar{b}}{\bar{\gamma}} \tilde{y}_{t-1}^{3}
$$

where: $\tilde{\tilde{y}}_{t}$ is the mean of $\bar{y}_{t} ; \bar{b}=\frac{1}{N} \sum_{i=1}^{N} b_{i}$.

Therefore, it follows that equation (12) can be written as the following non-linear crosssectionally augmented DF (NCADF) regression:

$$
\Delta \bar{y}_{i, t}=a_{i}+b_{i} \bar{y}_{i, t-1}^{3}+c_{i} \Delta \tilde{y}_{t}+d_{i} \Delta \tilde{y}_{t-1}^{3}+\varepsilon_{i, t}
$$

Given the framework above, the authors develop a unit root test in the heterogeneous panel model based on equation (14). Extending the idea of Kapetanios et al. (2003), the authors derive t-statistics on $\hat{b}_{i}$, which are denoted by:

$$
t_{i N L}(N, T)=\frac{\hat{b}_{i}}{\text { s.e. }\left(\hat{b}_{i}\right)},
$$

where: $\hat{b}_{i}$ is the OLS estimate of $b_{i} ;$ s.e. $\left(\hat{b}_{i}\right)$ is its associated standard error.

Following Pesaran (2007), the t-statistic in equation (15) can be used to construct a panel unit root test by averaging the individual test statistics:

$$
\bar{t}_{i N L}(N, T)=\frac{1}{N} \sum_{i=1}^{N} t_{i N L}(N, T)
$$

This is a non-linear cross-sectionally augmented version of the IPS test (NCIPS). Con-

\begin{tabular}{|c|c|c|c|c|}
\hline \multicolumn{3}{|c|}{$\begin{array}{l}\text { January } 1994- \\
\text { December } 2004\end{array}$} & \multicolumn{2}{|c|}{$\begin{array}{l}\text { January } 2005- \\
\text { February } 2010\end{array}$} \\
\hline City & t-stat & & City & t-stat \\
\hline Istanbul & -6.059 & $* * *$ & Istanbul & -1.980 \\
\hline Ankara & -3.227 & $* * *$ & Ankara & -0.645 \\
\hline Izmir & -3.5081 & $* * *$ & Izmir & -1.453 \\
\hline
\end{tabular}
sequently, Pesaran (2007) calculates critical values of both individual and panel NCADF tests for varying cross section and time dimensions.

Table 4. Test of rental price convergence individual NCADF

Critical values $(\mathrm{N}=3, \mathrm{~T}=132)$ :

\begin{tabular}{|c|c|c|c|}
\hline \multicolumn{2}{|c|}{$\begin{array}{l}\text { January } 1994 \text { - } \\
\text { December } 2004\end{array}$} & \multicolumn{2}{|c|}{$\begin{array}{l}\text { January } 2005 \text { - } \\
\text { February } 2010\end{array}$} \\
\hline & t-stat & & t-stat \\
\hline NCADF & $-4.265 * * *$ & NCADF & -1.359 \\
\hline \multicolumn{4}{|c|}{ Critical values $(\mathrm{N}=3, \mathrm{~T}=132)$ : } \\
\hline $1 \%$ & -2.42 & & \\
\hline $5 \%$ & -2.22 & & \\
\hline $10 \%$ & -2.11 & & \\
\hline
\end{tabular}

$1 \% \quad-3.71$

$5 \% \quad-3.12$

$10 \% \quad-2.80$

Note : *** denote $1 \%$.

Source: Cerrato et al. (Table 11, pp. 25, 2009)

Table 5. Panel test of rental price convergence

Note: $* * *$ denote $1 \%$ critical value.

Source: Cerrato et al. (Table 11, pp. 25, 2009) 
Furthermore, Table 4 reports the CADF test results as proposed by Cerrato's NCADF test. The results indicate that all cities exhibit rental price convergence towards the Turkish mean level at the $1 \%$ significance level from January 1994 to December 2004. In contrast, none of the cities show evidence of convergence from January 2005 to February 2010. The evidence clearly shows rental price divergence in Turkish property market. The result of nonlinear panel unit root test in Table 5 also provides the same conclusion as Table 4.

\section{CONCLUSION AND FURTHER RESEARCH}

In this paper, we investigate the rent convergence hypothesis by using monthly CPI inflation rates for Rent data in Turkey. After the recession in the early 2000s, Turkish housing market has grown on average yearly $11 \%$ in the period of 2002-2007. The property prices and rents also increased quickly during this period. However, the global economic crisis and some domestic factors have pushed the Turkish housing market into a recession at the late of 2000 s.

We examine the hypothesis of nonlinear rental price convergence using relative rental price index of three major cities namely, Istanbul, Izmir, and Ankara span from the period from January, 1994 to February, 2010. Using a new non-linear panel ADF test under crosssectional dependence, which is based on the Exponential Smooth Transition Autoregressive (ESTAR) model as advocated by Cerrato et al. (2009) the hypothesis of rental price convergence towards its national average rental index for three major cities in Turkey rental market is investigated.

Our results indicate that all cities exhibit rental price convergence towards its national mean level for the period of January 1994 to December 2004. In contrast, none of the cities show evidence of convergence from January 2005 to February 2010. The evidence clearly shows rental price divergence in Turkish property market.

The empirical result indicates that evidence of both linear and nonlinear convergence is lacking in the era of globalization in the period of January 2005 to February 2010. Lau (2010) finds evidence of provincial income divergence using Cerrato's NCADF test for the period 1952-2005. His finding for Chinese provincial growth dynamics suggests further study on conditional convergence, whereas heterogeneous factor difference may hinder beta convergence across provinces. Those factors may include inflation rate, infrastructure, human capital, degree of openness, and use of foreign capital among provinces. The findings support the implication of the proposition suggested by Young (2000) that there is increasing local protectionism in China. Along this strand of study we suggests further research on the rent convergence in Turkish property market should investigate heterogeneous factor difference in those three Turkish cities, that may hinder rent convergence dynamics in the era of globalization. Those factors may include prime loan rate, inflation rate, degree of market openness in terms of regulations and rules, agency commissions, legal fees, and property tax across cities.

\section{REFERENCES}

Akin, C. (2008) Housing market characteristics and estimation of housing wealth in Turkey. Available at: http://papers.ssrn.com/sol3/papers. cfm?abstract_id=1331324

Akkoyunlu, S. and Siliverstovs, B. (2010) Does the law of one price hold in a high-inflation environment? A tale of two cities in Turkey, KOF Working Paper, 248.

Alexander, C. and Barrow, M. (1994) Seasonality and cointegration of regional house prices in the UK, Urban Studies, 31(10), pp. 1667-1689. doi:10.1080/00420989420081571 
Andre, C. (2010) A bird's eye view of OECD housing markets, OECD Economics Department Working Paper, 746.

Ashworth, J. and Parker, S. (1997) Modelling regional house prices in the UK, Scottish Journal of Political Economy, 44(3), pp. 225-246. doi:10.1111/1467-9485.00055

Bektas, E. (2007) The persistence of profits in the Turkish banking system, Applied Economics Letters, 14(3), pp. 187-190. doi:10.1080/13504850500426178

Berg, L. (2002) Prices on the second-hand market for Swedish family houses: correlation, causation and determinants, International Journal of Housing Policy, 2(1), pp. 1-24. doi:10.1080/14616710110120568

Bilgin, M. H., Lau, C. K. M. and Tvaronavičienè, M. (2010) Is China integrated with her major trading partners: evidence on financial and real integration, Technological and Economic Development of Economy, 16(2), pp. 173-187. doi:10.3846/tede.2010.11

Burger, P. and Van Rensburg, L. J. (2008) Metropolitan house prices in South Africa: do they converge?, South African Journal of Economics, 76(2), pp. 291-297.

doi:10.1111/j.1813-6982.2008.00190.x

Carreras-i-Solanas, M., Mascarilla-i-Miro, O. and Yegorov, Y. (2004) The evolution and the relationship of house prices and rents in Barcelona,1970-2002, International Journal of Housing Policy, 4(1), pp. 19-56. doi:10.1080/1461671042000215442

Cerrato, M., Peretti. C., Larsson, R. and Sarantis, N. (2009) A non-linear panel unit root test under cross section dependence, Working paper, Department of Economics, University of Glasgow.

Chien, M. (2010) Structural breaks and the convergence of regional house prices, Journal of Real Estate Finance and Economics, 40(1), pp. 77-88. doi:10.1007/s11146-008-9138-y

Chien, M., and Lee, S. C. (2006) The convergence of regional house price: an application to Taiwan. In: Cheng, H. D., Chen, S. D. and Lin, R. Y. (eds.), Proceedings of the $9^{\text {th }}$ Joint Conference on Information Sciences (JCIS), The Splendor Kaohsiung, Kaohsiung, Taiwan, ROC, 8-11 October, 2006.

Clark, S. P. and Coggin, T. D. (2009) Trends, cycles and convergence in U.S. regional house prices,
Journal of Real Estate Finance and Economics, 39(3), pp. 264-283.

doi:10.1007/s11146-009-9183-1

Cook, S. (2003) The convergence of regional house prices in the UK, Urban Studies, 40(11), pp. 2285-2294.

doi:10.1080/0042098032000123295

Cook, S. (2005) Regional house price behaviour in the UK: application of a joint testing procedure, Physica A: Statistical Mechanics and its Applications, 345(3-4), pp. 611-621.

Cook, S. and Thomas, C. (2003) An alternative approach to examining the ripple effect in UK house prices, Applied Economics Letters, 10(13), pp. 849-851.

doi:10.1080/1350485032000143119

Drake, L. (1995) Testing for convergence between UK regional house prices, Regional Studies, 29(4), pp. 357-366. doi:10.1080/00343409512331349023

Elliott, G., Rothenberg, T. J. and Stock, J. H. (1996) Efficient tests for an autoregressive unit root, Econometrica, 64(4), pp. 813-836. doi:10.2307/2171846

Ferrara, L. and Koopman, S. J. (2009) Common business and housing market cycles in the Euro area from a multivariate decomposition, Banque de France, 275.

Galin, J. (2008) The long-run relationship between house prices and rents, Real Estate Economics, 36(4), pp. 635-658.

doi:10.1111/j.1540-6229.2008.00225.x

Gros, D. (2007) Bubbles in real estate? A longerterm comparative analysis of housing prices in Europe and the US, CEPS Working Documents, 239.

Hargreaves, B. (2008) What do rents tell us about house prices?, International Journal of Housing Markets and Analysis, 1(1), pp. 7-18. doi:10.1108/17538270810861120

Holmes, M. J. (2007) How convergent are regional house prices in the United Kingdom? Some new evidence from panel data unit root testing, Journal of Economic and Social Research, 9(1), pp. 1-17.

Holmes, M. J. and Grimes, A. (2005) Is there longrun convergence of regional house prices in the UK?, Motu Working Paper 05-11, Motu Economic and Public Policy Research Trust.

Im, K. S., Pesaran, H. and Shin, Y. (2003) Testing for unit roots in heterogeneous panels, Journal 
of Econometrics, 115(1), pp. 53-74.

doi:10.1016/S0304-4076(03)00092-7

ISPAT (2010) Real estate industry report, Investment Support and Promotion Agency of Turkey, Republic of Turkey Prime Ministry. Available at: http://www.invest.gov.tr/en-US/infocenter/ publications/Documents/REAL.ESTATE.INDUSTRY.PDF

Kapetanios, G., Shin, Y. and Snell, A. (2003) Testing for a unit root in the nonlinear STAR framework, Journal of Econometrics, 112(2), pp. 359-379. doi:10.1016/S0304-4076(02)00202-6

Keskin, B. (2008) Hedonic analysis of price in the Istanbul housing market, International Journal of Strategic Property Management, 12(2), pp. 125-138.

doi:10.3846/1648-715X.2008.12.125-138

Klyuev, V. (2008) What goes up must come down? House price dynamics in the United States, IMF Working Paper 187, International Monetary Fund.

Kwiatkowski, D., Phillips, P. C. B., Schmidt, P. and Shin, Y. (1992) Testing the null hypothesis of stationarity against the alternative of a unit root: how sure are we that economic time series have a unit root?, Journal of Econometrics, 54(1-3), pp. 159-178.

doi:10.1016/0304-4076(92)90104-Y

Larraz-Iribas, B. and Alfaro-Navarro, J. L. (2008) Asymmetric behaviour of Spanish regional house prices, International Advances in Economic Research, 14(4), pp. 407-421. doi:10.1007/s11294-008-9166-7

Lau, C. K. M. (2009) A more powerful panel unit root test with an application to PPP, Applied Economics Letters, 16(1), pp. 75-80. doi:10.1080/13504850701735815

Lau, C. K. M. (2010) New evidence about regional income divergence in China, China Economic Review, 21(2), pp. 293-309. doi:10.1016/j.chieco.2010.01.003

Leybourne, S. J. (1995) Testing for unit roots using forward and reverse Dickey-Fuller regressions, Oxford Bulletin of Economics and Statistics, 57(4), pp. 559-571.

Liu, C., Luo, Z. Q., Ma, L. and Picken, D. (2008) Identifying house price diffusion patterns among Australian state capital cities, International Journal of Strategic Property Management, 12(4), pp. 237-250.

doi:10.3846/1648-715X.2008.12.237-250
Luo, Z. Q., Liu, C. and Picken, D. (2007) Housing price diffusion pattern of Australia's state capital cities, International Journal of Strategic Property Management, 11(4), pp. 227-242.

MacDonald, R. and Taylor, M. P. (1993) Regional house prices in Britain: long-run relationships and short-run dynamics, Scottish Journal of Political Economy, 40(1), pp. 43-55. doi:10.1111/j.1467-9485.1993.tb00636.x

Maddala, G. S. and Wu, S. (1999) A comparative study of unit root tests with panel data and a new simple test, Oxford Bulletin of Economics and Statistics, 61, pp. 631-652. doi:10.1111/1468-0084.61.s1.13

Maddala, G. S. and Kim, I. M. (1998) Unit roots, cointegration and structural change. Cambridge, Cambridge University Press.

Michael, P., Nobay, A. R. and Peel, D. A. (1997) Transaction costs and nonlinear adjustment in real exchange rates: an empirical investigation, Journal of Political Economy, 105(4), pp. 862-879. doi:10.1086/262096

Onder, Z., Dokmeci, V. and Keskin, B. (2004) The impact of public perception of earthquake risk on Istanbul's housing market, Journal of Real Estate Literature, 12(2), pp. 181-194.

Otrok, C. and Terrones, M. E. (2005) House prices, interest rates and macroeconomic fluctuations: international evidence. Available at: http://www.frbatlanta.org/news/conferen/housing2005/otrok_terrones.pdf

Ozcicek, O. (2007) Price convergence among provinces in Turkey, Akdeniz I.I.B.F. Dergisi, 13, pp. 266-279.

Ozus, E., Dokmeci, V., Kiroglu, G. and Egdemir, G. (2007) Spatial analysis of residential prices in Istanbul, European Planning Studies, 15(5), pp. 707-721. doi:10.1080/09654310701214085

Park, H. J. and Fuller, W. A. (1995) Alternative estimators and unit root tests for the autoregressive process, Journal of Time Series Analysis, 16(4), pp. 415-429. doi:10.1111/j.1467-9892.1995.tb00243.x

Pedroni, P. and Yao, J. Y. (2006) Regional income divergence in China, Journal of Asian Economics, 17(2), pp. 294-315. doi:10.1016/j.asieco.2005.09.005

Perron, P. and Ng, S. (1996) Useful modifications to some unit root tests with dependent errors and their asymptotic properties, Review of 
Economic Studies, 63(3), pp. 435-463. doi:10.2307/2297890

Pesaran, M. H. (2007) A simple panel unit root test in the presence of cross-section dependence, Journal of Applied Econometrics, 22(2), pp. 265-312. doi:10.1002/jae.951

Republic of Turkey Ministry of Finance (2009) Yıllık Ekonomik Rapor. (In Turkish)

Selim, S. (2008) Determinants of house prices in Turkey: a hedonic regression model, Doguş Universitesi Dergisi, 9(1), pp. 65-76.

Standard and Poors (2007) Structured finance in Turkey: existing asset securitization market on track to develop in 2007. Available at: http:// www2.standardandpoors.com/spf/pdf/media/ turkey_sf_turkey_viewpoint.pdf

Stevenson, S. (2004) House price diffusion and inter-regional and cross-border house price dynamics, Journal of Property Research, 21(4), pp. 301-320. doi:10.1080/09599910500151228

Taylor, A. M. and Taylor M. P. (2004) The purchasing power parity debate, Journal of Economic Perspectives, 18(4), pp. 135-158. doi:10.1257/0895330042632744

Taylor, M. P., Peel, D. A. and Sarno, L. (2001) Nonlinear mean-reversion in real exchange rates: toward a solution to the purchasing power parity puzzles, International Economic Review, 42(4), pp. 1015-1042. doi:10.1111/1468-2354.00144

Tunay, B. K. and Silpagar, A. M. (2007) Regional inflation convergence analysis in Turkey with dynamic space-time panel data models, Gazi
Üniversitesi İktisadi ve İdari Bilimler Fakültesi Dergisi, 9(1), pp. 1-27.

Turhan, I. (2008) Housing sector in Turkey: challenges and opportunities, $17^{\text {th }}$ Annual International Conference, The American Real Estate and Urban Economics Association, Istanbul, 4 July. Available at: http://www.tcmb.gov.tr/yeni/ iletisimgm/Turhan_HousingSector.pdf

TurkStat (2009) Statistical indicators 1923-2008, Turkish Statistical Institute, Ankara.

Tvaronavičienè, M., Grybaitè, V. and Tvaronavičienè, A. (2009) If institutional performance matters: development comparisons of Lithuania, Latvia and Estonia, Journal of Business Economics and Management, 10(3), pp. 271-278. doi:10.3846/1611-1699.2009.10.271-278

Vansteenkiste, I. (2007) Regional housing market spillovers in the US: lessons from regional divergences in a common monetary policy setting, European Central Bank Working Paper Series, 708.

Vansteenkiste, I. and Hiebert, P. (2009) Do house price developments spill over across Euro area countries? Evidence from a global VAR, European Central Bank Working Paper Series, 1026.

Yilmazkuday, H. (2009) Inflation targeting and inflation convergence within Turkey. Available at: http://mpra.ub.uni-muenchen.de/16770/

Young, A. (2000) The razor's edge: distortions and incremental reform in the People's Republic of China, Quarterly Journal of Economics, 115(4), pp. 1091-1135. doi:10.1162/003355300555024

\section{SANTRAUKA}

\section{RENTOS KAINŲ KONVERGENCIJA BESIVYSTANČIOJE EKONOMIKOJE}

\section{Mehmet Huseyin BILGIN, Chi Keung Marco LAU, Ender DEMIR, Nijolè ASTRAUSKIENĖ}

Darbe tikrinama triju pagrindiniu Turkijos miestu - Stambulo, Izmiro ir Ankaros - netiesinès rentos kainu konvergencijos hipotezè nuo $1994 \mathrm{~m}$. sausio mèn. iki $2010 \mathrm{~m}$. vasario mèn., taikant santykini rentos kainu indeksa. Tyrimu rezultatai rodo, kad nuo $1994 \mathrm{~m}$. sausio mèn. iki $2004 \mathrm{~m}$. gruodžio mèn. visuose miestuose rentos kainos artëjo prie vidutinio nacionalinio lygio. Priešingai, tokios konvergencijos irodymų negauta nè vieno miesto atžvilgiu nuo 2005 m. sausio mèn. iki 2010 m. vasario mėn. Faktai aiškiai rodo Turkijos nekilnojamojo turto rinkos rentos kainų divergencija. 